\title{
TEKNIK PENGAWETAN FILLET IKAN NILA MERAH DENGAN SENYAWA ANTI BAKTERI ASAL LACTOBACILLUS ACIDOPHILUS DAN BIFIDO BACTERIA BIFFIDUM
}

\author{
Dede Saputra $^{1}$; Tati Nurhayati ${ }^{2}$ \\ ${ }^{1}$ Industrial Engineering Department, Faculty of Engineering, Binus University \\ Jl. Alam Sutera Boulevard No. 1. Alam Sutera - Serpong Tangerang 15325 \\ ${ }^{2}$ Department of Aquatic Product Technology, Faculty of Fisheries and Marine Sciences \\ Institut Pertanian Bogor. \\ Jl. Lingkar Akademik Wing III, Gedung FPIK, IPB, Bogor 16116 \\ ddsaputra@binus.ac.id; ddsaputra87@gmail.com
}

\begin{abstract}
Red tilapia is a good commodity to be developed because it has a high nutritional value composition, with a protein content $17.8 \%$, fat $2.8 \%$, and others composition. The fillet of red tilapia fish is easy to spoil, because of $S$. aureus, Salmonella sp., and other microbes. Many methods are used to save and preserve the quality of fillet, such fillet preparation through good sanitation practices, cooling process, but the effort were not optimal. The objectives of this study were to 1) evaluate the potency of antibacterial produced by Lactobacillus acidophilus and Bifidobacteria biffidum to inhibit the growth of spoilage bacteria that contaminated the red tilapia fillet; 2) evaluate the effect of antibacterial compounds produced by Lactobacillus acidophilus and Bifidobacteria biffidum of inhibiting the setback fillet quality, 3) determine the shelf life of red tilapia fillet at room temperature. Antibacterial activity test is done by using the well diffusion method; the rate of deterioration of quality of fish tests done by observing the organoleptic parameters, $p H$ measurement test, total volatile base method. Total number of bacteria were performed by Standard Plate Count (SPC) test. The LAB's are able to inhibit the growth of spoilage bacteria Pseudomonas aeruginosa about 8.67-9.00 mm and Listeria monocytogenes about 8.33-9.00 mm through the well diffusion method. pH values about 5.71-5.74, TVB values about 1,26-21.43 with SPC test about 1.39-4.83 CFU/mL. The antibacterial compounds could inhibit the rate of deterioration of quality red tilapia fillets until 14 hours.
\end{abstract}

Keywords: preserving, fillet, red tilapia, antibacterial, $L A B$

\begin{abstract}
ABSTRAK
Ikan nila merupakan komoditas yang sangat baik untuk dikembangkan karena memiliki komposisi nilai gizi yang tinggi, dengan kandungan protein sebesar 17,8\%, lemak 2,8\%, dan komposisi lainnya. Filet ikan nila merah mudah mengalami kerusakan, karena S. aureus, Salmonella sp., dan mikroba lainnya. Banyak metode yang telah digunakan untuk menyimpan dan mengawetkan filet, seperti penerapan praktik sanitasi yang baik, proses pembekuan, tetapi upaya itu tidak optimal. Tujuan dari penelitian ini adalah pertama, mengevaluasi potensi antibakteri yang dihasilkan oleh Lactobacillus acidophilus dan Bifidobacteria biffidum untuk menghambat pertumbuhan bakteri pembusuk yang mengontaminasi filet nila merah. Kedua, mengevaluasi efek senyawa antibakteri yang dihasilkan oleh Lactobacillus acidophilus dan Bifidobacteria biffidum dalam menghambat kualitas kemunduran mutu filet. Ketiga, menentukan umur simpan filet nila merah pada suhu kamar. Uji aktivitas antibakteri dilakukan dengan menggunakan metode sumur difusi; uji kemunduran mutu ikan dilakukan dengan mengamati parameter organoleptik, pengukuran $\mathrm{pH}$, metode jumlah total basa volatil. Total jumlah bakteri dilakukan dengan Standard Plate Count (SPC). BAL ini dapat menghambat pertumbuhan bakteri pembusuk Pseudomonas aeruginosa sekitar 8,67-9,00 $\mathrm{mm}$ dan Listeria monocytogenes sekitar 8,33-9,00 mm melalui metode sumur difusi. Nilai pH sekitar 5,71-5,74, nilai TVB sekitar 1,26-21.43 dengan assai SPC sekitar 1,39-4,83 CFU / mL. Senyawa antibakteri dapat menghambat laju kerusakan filet nila merah sampai 14 jam.
\end{abstract}

Kata kunci: pengawetan, filet, nila merah, antibakteri, $B A L$ 


\section{PENDAHULUAN}

Nila merah merupakan salah satu jenis ikan budi daya air tawar yang mempunyai prospek cukup baik untuk dikembangkan. Kusumawardhani (1988) dalam Rostini (2007), nilai gizi protein nila merah per $100 \mathrm{~g}$ daging adalah 17,8\%; lemak 2,8\%; mineral 1,2\% dan kandungan senyawa gizi lainnya. Dewasa ini hasil olahan nila merah yang umum disukai oleh masyarakat adalah fillet ikan. Fillet ikan nila merah produk pangan yang sangat mudah mengalami kerusakan (perishable food), salah satunya adalah kerusakan yang diakibatkan oleh aktivitas mikroba pembusuk seperti Staphylococcus aureus, Salmonella sp. dan lainnya.

Banyak cara yang dapat dilakukan untuk menyelamatkan dan mempertahankan mutu fillet ikan, antara lain adalah preparasi fillet melalui praktek sanitasi yang baik dan proses pendinginan, namun upaya itu belum optimal. Dewasa ini beberapa cara pengawetan telah dilakukan untuk menyelamatkan produk hasil perikanan, salah satunya pemanfaatan kelompok antimikroba peptida bakteri Gram positif, terutama bakteri asam laktat yang telah banyak dimanfaatkan sifat antagonistiknya dalam bidang biopreservasi pangan (food preservative) dan antibakterial (antibacterial agent) penghambat bakteri patogenik Gram positif (Jack et al. 1995).

Penggunaan biopreservatif yang berasal dari bakteri asam laktat (BAL) pada pangan dilakukan karena dapat memperpanjang waktu penyimpanan dan menekan jumlah mikroorganisme yang tidak diinginkan. Bakteri ini tidak bersifat toksik sehingga aman untuk dikonsumsi, yang dikenal dengan sebutan food grade microorganism (Holzapfel et al. 1995). BAL dapat menurunkan $\mathrm{pH}$ bahan pangan. Penurunan $\mathrm{pH}$ tersebut dapat memperlambat pertumbuhan mikroorganisme pembusuk (Buckle et al. 1987).

Tujuan dari studi ini adalah untuk: (1) Mempelajari aktivitas senyawa antibakteri asal Lactobacillus acidophilus dan Bifidobacteria biffidum dalam menghambat pertumbuhan bakteri patogen pada fillet ikan nila merah. (2) Mempelajari pengaruh senyawa antibakteri asal Lactobacillus acidophilus dan Bifidobacteria biffidum dalam menghambat kemunduran mutu fillet ikan nila merah. (3) Mengetahui efektivitas senyawa antibakteri asal Lactobacillus acidophilus dan Bifidobacteria biffidum dalam memperpanjang umur simpan produk fillet ikan nila merah pada suhu ruang, melalui pengamatan parameter $\mathrm{pH}$, analisis sensori, dan analisis biokimia daging fillet ikan nila.

\section{METODE}

Bahan yang digunakan pada studi ini terdiri dari bahan utama yang meliputi isolat bakteri asam laktat yakni Lactobacillus acidophilus, Biffidobacteria biffidum (yang diperoleh dari FTP UGM), bakteri uji Pseudomonas aeruginosa, Staphylococcus aureus (yang diperoleh dari lab Mikrobiologi SEAFAST Center IPB). Media yang digunakan adalah jus wortel (sayur), Mann Rogosa Sharpe Agar (MRSA) (Oxoid CM0361), Mann Rogosa Sharpe Broth (MRSB) (Oxoid CM0359), Nutrient Agar (NA), Nutrient broth (NB), Pepton Water (Oxoid), media Plate Count Agar (PCA), dan MRSA-AA (MRSA- acetic acid), kalium dihidrogen posfat $\left(\mathrm{KH}_{2} \mathrm{PO}_{4}\right)$ dan bahan analisis mirobiologi standar lainnya. Alat-alat yang digunakan pada penelitian ini Hot plate (Steroglass), $\mathrm{pH}$ Meter (Orion 2 star $\mathrm{pH}$ Bench top), Autoklaf (ALP Model-40), cawan petri (Pyrex), dan alat-alat analisis mikrobiologi standar lainnya.

\section{Persiapan bakteri uji}

Bakteri yang digunakan untuk pengujian aktivitas antibakteri asal Lactobacillus acidophilus dan Biffidobacteria biffidum pada media jus wortel adalah Pseudomonas aeruginosa dan Staphylococcus aureus. Bakteri-bakteri uji ini sebelumnya ditumbuhkan pada media agar miring NA 
yang disimpan pada suhu refrigerasi. Bakteri sebelum digunakan maka perlu disegarkan terlebih dahulu pada media cair NB dan diinkubasi selama 24 jam pada suhu $37{ }^{\circ} \mathrm{C}$.

\section{Uji aktivitas antibakteri (Bodade et al. 2008; Garriga et al. 1993)}

Uji aktivitas antibakteri dilakukan dengan menggunakan metode agar difusi sumur terhadap bakteri Pseudomonas aeruginosa dan Staphylococcus aureus. Media NA yang mengandung bakteri uji $10^{7} \mathrm{CFU} / \mathrm{ml}$ dituang ke cawan petri steril dan dibiarkan membeku, setelah itu, kemudian pada media tersebut dibuat sumu-sumur dengan diameter $6 \mathrm{~mm}$. Ke dalam lubang tersebut dimasukan masingmasing $60 \mathrm{ml}$ senyawa antimikroba yang telah diperoleh dari bakteri Lactobacillus acidophilus dan Biffidobacteria biffidum yang ditumbuhkan pada media jus wortel pasteurisasi. Selanjutnya cawan diinkubasi pada inkubator suhu $37^{\circ} \mathrm{C}$ selama $24-48$ jam.

\section{Pengukuran Derajat Keasaaman (pH) (Manual pH meter 2006)}

Sampel sebanyak $20 \mathrm{~mL}$, dihomogenkan dan dibiarkan 15 menit. Selanjutnya diukur nilai pHnya dengan $\mathrm{pH}$ meter yang telah dikalibrasi dengan buffer $\mathrm{pH} 4,0$ dan $\mathrm{pH} 7,0$. Nilai $\mathrm{pH}$ diukur sebanyak tiga kali ulangan.

\section{Analisis Organoleptik (BSN 2006)}

Uji organoleptik bertujuan untuk mengetahui tingkat penerimaan konsumen terhadap produk fillet ikan nila merah yang telah ditambah isolat BAL. Uji organoleptik yang dilakukan adalah uji hedonik menggunakan 15 orang panelis tidak terlatih dan semi terlatih. Parameter yang diujikan meliputi atribut warna, aroma, tekstur, rasa, dan keseluruhan (overall). Penyajian sampel dilakukan satu per satu secara bergantian untuk mendapatkan penilaian yang objektif dari panelis.

\section{Uji Total Volatile Base (TVB) (AOAC 1984)}

Penetapan ini bertujuan untuk menentukan jumlah kandungan senyawa-senyawa basa volatil yang terbentuk akibat degradasi protein. Prinsip dari analisa TVB adalah menguapkan senyawasenyawa basa volatil (amin, mono-, di-, dan trimetilamin) pada suhu kamar selama 24 jam. Senyawa tersebut kemudian diikat oleh asam borat dan kemudian dititrasi dengan larutan $\mathrm{HCl}$.

$$
\% N=\frac{m L H C l-m L \text { blanko } \times N \mathrm{HCl} \times 14,007 \times 100 \%}{m g \text { contoh }}
$$

\section{Penghitungan Koloni (BAM 2001)}

Jumlah koloni bakteri dapat dihitung setelah diinkubasi pada suhu $35^{\circ} \mathrm{C}$ selama 48 jam. Koloni bakteri dapat dihitung dengan rumus Standard Plate Count sebagai berikut:

$$
N=\Sigma C /\left\{\left[\left(1^{*} n_{1}\right)+\left(0,1^{*} n_{2}\right)+\ldots\right]^{*}(d)\right\}
$$

Di mana : $\quad \mathrm{N} \quad=$ jumlah koloni per $\mathrm{mL}$ atau per gram produk

$\Sigma \mathrm{C}=$ jumlah semua koloni yang dihitung dari 2 cawan

$\mathrm{n}_{1} \quad=$ jumlah cawan pada pengenceran pertama

$\mathrm{n}_{2} \quad=$ jumlah cawan pada pengenceran kedua

$\mathrm{d} \quad=$ pengenceran pertama yang dihitung 
Limit deteksi metode plating berkisar 25 hingga 250 koloni. Ketika dalam cawan terdapat koloni kurang dari 25 , maka dalam pelaporannya dikatakan bahwa jumlahnya $<2,5 \times 10^{1} \mathrm{CFU} / \mathrm{mL}$. Jika tidak ditemukan koloni dalam cawan hingga pengenceran terendah, maka pelaporannya sebanyak 1,0x $10^{1} \mathrm{CFU} / \mathrm{mL}$. Namun, jika koloninya melebihi 250, maka dianggap sebagai TBUD (tidak bisa untuk dihitung). Dengan demikian, hanya cawan yang jumlah koloninya berkisar 25 hingga 250 saja yang dapat dihitung sebagai jumlah koloni bakteri yang diinokulasikan.

\section{Analisis Data}

Analisis statistika yang digunakan pada penelitian ini meliputi analisis deskriptif dan analisis kuantitatif. Analisis deskriptif digunakan untuk mendeskripsikan pengaruh penggunaan BAL dalam menjaga stabilitas produk fillet selama masa simpan (fase kemunduran mutu). Rancangan Acak Lengkap dengan tiga kali ulangan, hasil beda nyata dianalisis dengan uji lanjut beda nyata terkecil (BNT) dengan software SPSS 16.0 (Steel \& Torrie 1980; Uyanto 2009) dan data grafik yang diperoleh pada penelitian dianalisis Sigma-Plot 11.0.

\section{HASIL DAN PEMBAHASAN}

\section{Perubahan Nilai pH Galur L. acidophilus, Bifidobacterium biffidum dan Campuran Bakteri Selama Masa Simpan}

Parameter $\mathrm{pH}$ merupakan parameter penting dalam menentukan kemampuan suatu mikroorganisme untuk dapat bertahan hidup pada suatu lingkungan. Bakteri asam laktat merupakan mikroorganisme fermentatif yang dapat hidup pada kisaran $\mathrm{pH}$ luas. Pertahanan utama sel bakteri dari lingkungannya adalah membran seluler yang terdiri atas struktur lemak dua lapis. Bila sel bakteri terpapar pada kondisi asam, maka membran sel dapat mengalami kerusakan dan berakibat hilangnya komponen-komponen intraseluler, seperti $\mathrm{Mg}$, K, dan lemak dari sel. Berikut Gambar 1, menunjukkan perubahan nilai $\mathrm{pH}$ bakteri asam laktat L. acidophilus, Bifidobacterium biffidum, dan campuran bakteri.

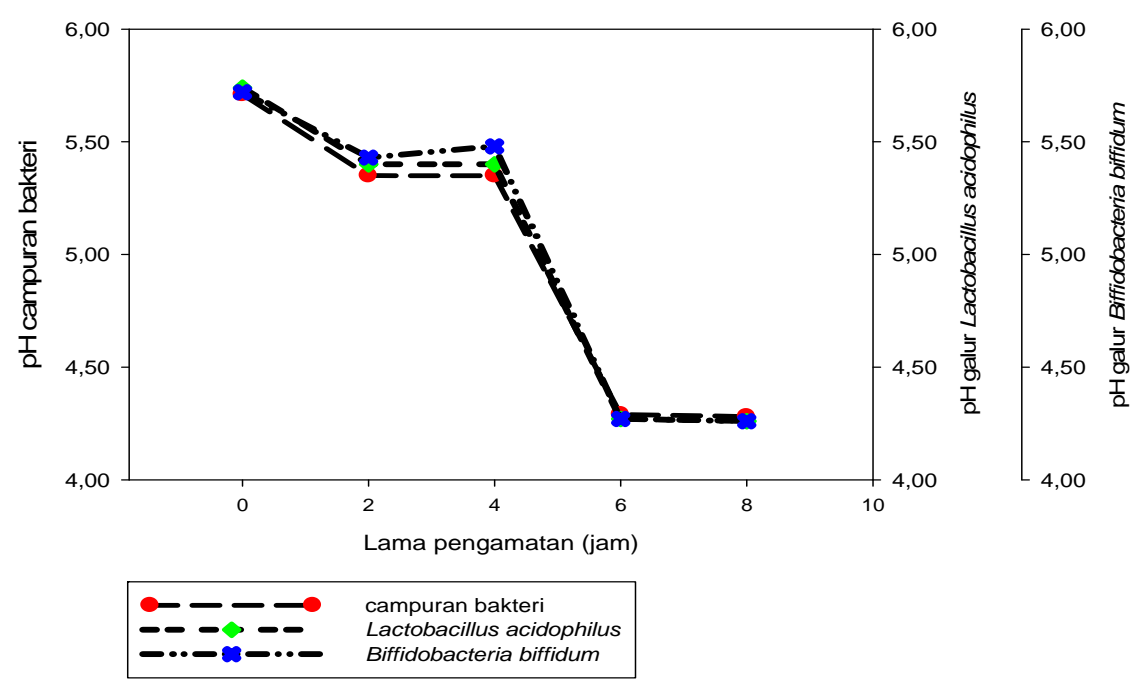

Gambar 1 Perubahan Nilai pH BAL Lactobacillus acidophilus, Biffidobacteria biffidum dan Campuran Selama Masa Simpan 0 Hingga 8 Jam Pada Media Wortel Pasteurisasi 
Gambar 1 menunjukkan terjadinya penurunan nilai $\mathrm{pH}$ baik pada BAL galur Lactobacillus acidophilus, Biffidobacteria biffidum maupun campuran kedua bakteri. pH BAL galur Lactobacillus acidophilus, Biffidobacteria biffidum, dan campuran pada pengamatan jam ke-0 masing-masing sebesar 5,74; 5,72; dan 5,71. Nilai $\mathrm{pH}$ media wortel pasteuriasi mengalami penurunan setelah diinkubasi 8 jam untuk masing-masing galur yakni mencapai pH 4,26 (galur Lactobacillus acidophilus dan Biffidobacteria biffidum), serta 4,28 untuk campuran bakteri.

Hasil yang diperoleh pada penelitian ini sesuai dengan laporan Barefoot \& Nettles (1993) yang mengatakan bahwa genus BAL Lactobacillus mampu memproduksi senyawa antibakteri, yaitu bakteriosin, hidrogen peroksida $\left(\mathrm{H}_{2} \mathrm{O}_{2}\right)$, karbondioksida, dan diasetil. Jenie dan Rini (1995) melaporkan bahwa penggunaan L. plantarum dan L. casei subsp Rhamnosus mampu memproduksi $\mathrm{H}_{2} \mathrm{O}_{2}$ dalam jumlah yang tinggi sehingga cukup potensial dalam menghambat pertumbuhan bakteri patogen melalui sifat bakterisidalnya.

Filtrat Lactobacillus dapat menghambat pertumbuhan beberapa bakteri patogen seperti Streptococcus, Staphylococcus aureus, dan E. coli, bahkan filtrat yang sudah disimpan selama 6 bulan memiliki kemampuan sama. Penurunan nilai $\mathrm{pH}$ yang cukup rendah yakni mencapai 4.0 menunjukkan bahwa galur-galur BAL yang digunakan memiliki aktivitas aktibakteri yang cukup baik. Kondisi $\mathrm{pH}$ rendah menyebabkan asam organik larut oleh lemak, kemudian memungkinkan menerobos membran sel dan mencapai sitoplasma patogen, disamping itu adanya kompetisi nutrisi, akumulasi D-asam amino dan menurunya potensi redoks juga memberikan pengaruh terhadap daya hambat terhadap patogen (Heller et al. 2001).

\section{Aktivitas antibakteri isolat Lactobacillus acidophilus dan Biffidobacteria biffidum}

Antibakteri berperan sebagai penghambat atau menginaktivasi mikroba patogen dengan menggunakan kemampuan antagonisnya dan beberapa galur BAL mampu memproduksi senyawa asam organik, diasetil, hidrogen peroksida dan bakteriosin (Oyetayo et al. 2003). Hasil penelitian yang diperoleh menunjukkan bahwa semua jenis galur BAL yang digunakan yakni Lactobacillus acidophilus, Biffidobacteria biffidum, dan campuran bakteri mempunyai daya hambat terhadap bakteri uji P. aeruginosa dan S.aureus dengan diameter penghambatan cukup besar pada Tabel 1.

Tabel 1 Diameter penghambatan BAL galur Lactobacillus acidophilus, Biffidobacteria biffidum, dan campuran bakteri terhadap bakteri uji

\begin{tabular}{lcc}
\hline \multirow{2}{*}{ Jenis galur } & \multicolumn{2}{c}{ Diameter penghambatan (mm) } \\
\cline { 2 - 3 } & Pseudomonas aeruginosa & Staphylococcus aureus \\
\hline Campuran bakteri & $9,00 \pm 1,00$ & $9,00 \pm 1,00$ \\
L. acidophilus & $8,67 \pm 0,50$ & $8,67 \pm 2,08$ \\
B. bifidum & $8,67 \pm 1,53$ & $8,33 \pm 2,08$ \\
\hline
\end{tabular}

Keterangan: data disajikan purata \pm standar deviasi

Tabel 1 menunjukkan bahwa diameter penghambatan terbesar terhadap bakteri indikator $P$. aeruginosa dan $S$. aureus dihasilkan oleh campuran bakteri BAL yaitu dengan zona hambat sebesar $9,00 \pm 1,00 \mathrm{~mm}$. Zona hambat yang cukup besar juga terlihat pada uji aktivitas antibakteri galur $L$. acidophilus dengan bakteri indikator $P$. aeruginosa dan $S$. aureus dengan luas zona hambat yang diberikan oleh BAL pada masing-masing bakteri indikator adalah sebesar 8,67 $\pm 0,50 \mathrm{~mm}$ dan $8,67 \pm 2,08 \mathrm{~mm}$. Daya hambat terhadap bakteri indikator terendah dihasilkan oleh BAL Bifidobacteria bifidum yakni sebesar $8,67 \pm 1,53 \mathrm{~mm}$ terhadap P. aeruginosa dan $8,33 \pm 2,08 \mathrm{~mm}$ terhadap S. aureus. 
Berdasarkan hasil yang diperoleh pada tahap ini terlihat bahwa penghambatan BAL tunggal dan campuran bakteri terhadap bakteri gram negatif ( $P$. aeruginosa) umumnya menunjukkan aktivitas lebih tinggi dari pada bakteri gram positif ( $S$. aureus). Hasil yang diperoleh pada penelitian ini sejalan dengan laporan Surono (2001) yang menunjukkan bahwa aktivitas antibakteri BAL dari berbagai sumber isolasi mempunyai daya penghambatan terhadap bakteri grma negatif E. coli. Setyawardani (2012) juga menjelaskan bahwa uji aktivitas antibakteri BAL jenis L. plantarum TW10 memiliki daya

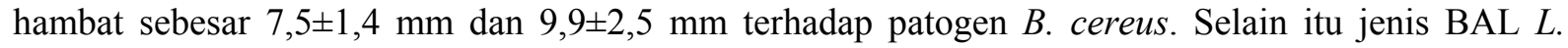
rhamnosus TW3 memilik daya hambat sebesar 10,4 $\pm 1,2 \mathrm{~mm}$ terhadap bakteri $S$. aureus. Yulinery et. al. (2009), pada penelitiannya melaporkan bahwa penggunaan isolat Lactobacillus Mar8 mampu menghambat pertumbuhan $S$. aureus dengan zona hambatan $8 \mathrm{~mm}$ pada suhu kamar dan refrigerator $\left(4^{\circ} \mathrm{C}\right)$, dan terhadap bakteri Vibrio sp. $13,25 \mathrm{~mm}$ pada suhu $4^{\circ}$ C. Ammor et. al (2005) dan (2006) melaporkan bahwa penggunaan BAL strain Lactobacillus sakei mampu menghambat pertumbuhan bakteri indikator Enterococcus sp (ELI-60), dengan zona hambat $<50 \mathrm{~mm}^{2}$. Daya hambatan ini disebabkan oleh adanya senyawa yang bersifat antibakteri yang dihasilkan Lactobacillus. Senyawa antibakteri yang dihasilkan Lactobacillus adalah asam organik, hidrogen peroksida, diasetil, dan bakteriosin (Barefoot dan Nettles 1993).

\section{Aplikasi Aktivitas Antibakteri Campuran bakteri BAL pada Fillet Nila Merah}

\section{Penentuan Fase Post Mortem Fillet Ikan Nila Merah dengan Parameter Uji Organoleptik dan Ph Fillet Ikan Nila Merah}

Penentuan fase post mortem ikan dilakukan untuk mengetahui serta mengenali kondisi tingkat kesegaran ikan pada beberapa fase post mortem. Setelah ikan mati, ikam mengalami kemunduran mutu meliputi fase pre rigor (hiperaemia), rigor mortis, post rigor dan busuk (Junianto 2003). Fillet ikan nila merah pada (penyimpanan jam ke-0), masih berada dalam kondisi segar atau disebut fase pre rigor (hiperaemia) yakni terjadi pada jam ke-0 pada kedua perlakuan. Pada fase ini ikan secara fisik memiliki nilai organoleptik berkisar pada selang kepercayaan 9,00 pada kedua perlakuan kontrol dan campuran bakteri berdasarkan pengujian bagi nilai tengah pada selang kepercayaan $95 \%$ dapat disimpulkan bahwa fillet ikan nila merah pada fase ini memiliki nilai rata-rata organoleptik sebesar 8,00 .

Nilai organoleptik ikan selar di atas, sesuai dengan kondisi ikan segar pada umumnya yang memiliki nilai orgonoleptik rata-rata 8,00-9,00 (BSN 2006). Untuk parameter $\mathrm{pH}$, fillet ikan nila

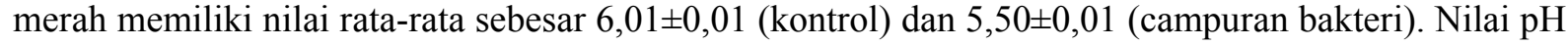
pada penelitian ini sesuai dengan pendapat Yunizal dan Wibowo (1998) yang mengatakan bahwa ikan yang baru mati umumnya mempunyai $\mathrm{pH}$ netral, yakni sekitar 6,0-7,0.

Fase rigor mortis terjadi setelah tiga jam penyimpanan (kontrol) dan empat jam penyimpanan pada campuran bakteri, yang ditandai dengan rata-rata nilai organoleptik dan $\mathrm{pH}$ yang sedikit menurun, masing-masing sebesar 7,00 (kontrol) dan (campuran bakteri). Sedangkan nilai pH masing-

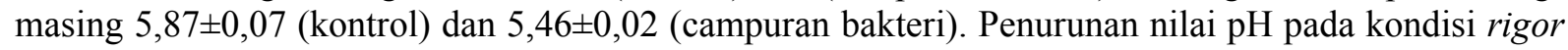
mortis ini terjadi akibat proses glikolisis yang mengubah glikogen dalam tubuh ikan menjadi asam laktat. Asam laktat yang terbentuk mengakibatkan nilai $\mathrm{pH}$ fillet ikan nila merah. Nilai $\mathrm{pH}$ minimal yang dapat tercapai setelah ikan mati tergantung dari cadangan glikogen yang terdapat di dalam daging ikan (Rahayu et al. 1992). Akhir dari fase rigor mortis merupakan awal dari proses post rigor.

Pada fase ini terjadi proses autolisis. Biasanya proses autolisis akan selalu diikuti dengan meningkatnya jumlah mikroba, sebab semua hasil penguraian enzim selama proses autolisis merupakan media yang cocok bagi pertumbuhan mikroba (Rahayu et al. 1992). Fase post rigor terjadi pada jam ke-6 (kontrol) dan jam ke-7 (campuran bakteri). Pada fase ini nilai uji organoleptik masing-masing sebesar 4,00 (kontol) dan 5,00 (campuran bakteri). 


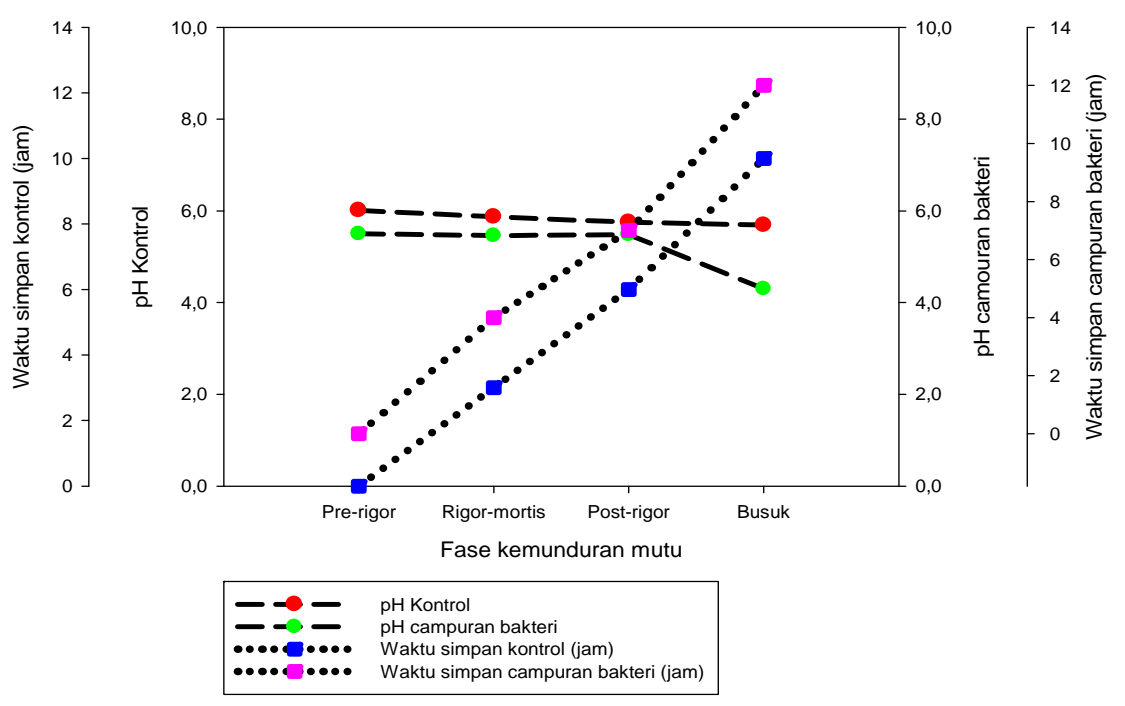

Gambar 2 Laju Kemunduran Mutu Fillet Ikan Nila Merah pada Campuran Bakteri dan Kontrol

(Parameter Pengamatan: Ph dan Waktu Penyimpanan)

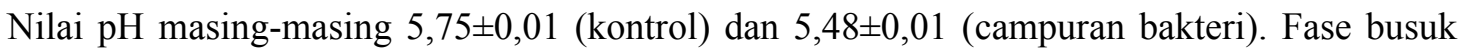
terjadi pada jam ke-10 (kontrol) dan ke-12 (campuran bakteri). Fillet ikan nila merah memiliki nilai uji organoleptik masing-masing sebesar 3,00 (kontol) dan 5,00 (campuran bakteri). Sedangkan nilai pH

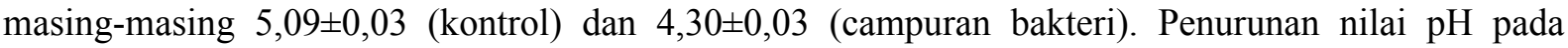
perlakuan campuran bakteri menunjukkan bahwa campuran bakteri mampu menghambat laju kemunduran mutu fillet lebih lama.

\section{Nilai TVBN dan TPC}

Total Volatile Base (TVB) nitrogen merupakan indikator kesegaran ikan yang didasarkan pada terbentuknya senyawa-senyawa basa dan amin. Senyawa amin merupakan hasil dekarboksilasi asam amino dan reduksi TMAO. Tingkat kesegaran hasil perikanan berdasarkan TVBN dikelompokkan menjadi empat (Farber Dalam Borgstorm, 2005), yaitu: a) ikan sangat segar dengan kadar TVBN 10 $\mathrm{mg} \mathrm{N} / 100 \mathrm{~g}$ atau lebih kecil; b) ikan segar 10-20 mg N/100 g; c) ikan yang masih dapat dikonsumsi 20-30 mg N/100 g; d) ikan busuk yang tidak dapat dikonsumsi dengan kadar lebih besar dari $30 \mathrm{mg}$ $\mathrm{N} / 100 \mathrm{~g}$.

Secara biokimiawi nilai TVBN pada saat pre rigor pada perlakuan kontrol dan campuran

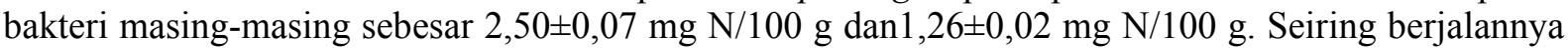
masa post mortem, fillet ikan nila merah pada fase rigor mortis memiliki nilai TVBN sebesar $15,12 \pm 0,01 \mathrm{mg} \mathrm{N} / 100 \mathrm{~g}$ (kontrol) dan 13,86 $\pm 0,10$ (kotail) $\mathrm{mg} \mathrm{N} / 100 \mathrm{~g}$. Memasuki fase post rigor nilai TVBN terus mengalami peningkatan yakni mencapai 35,29 $\pm 0,01 \mathrm{mg} \mathrm{N} / 100 \mathrm{~g}$ (kontrol) dan $20,17 \pm 0,17$ (kotail) $\mathrm{mg} \mathrm{N} / 100 \mathrm{~g}$. Pada fase busuk nilai TVBN perlakuan kontrol sangat besar yakni mecapai 40,34 $\pm 0,15 \mathrm{mg} \mathrm{N} / 100 \mathrm{~g}$, sedangkan pada perlakuan campuran bakteri nilai TVBN fillet ikan nila merah jauh lebih rendah dibandingkan dengan kontrol yakni 21,43 $\pm 0,14 \mathrm{mg}$ N/100 g. Nilai ini sesuai dengan klasifikasi Farber dalam Borgstorm (2005), yaitu pada saat pre rigor hingga busuk nilai TVBN yang dihasilkan sebesar $10 \mathrm{mg} \mathrm{N} / 100 \mathrm{~g}$ sampai dengan $>30 \mathrm{mg} \mathrm{N} / 100 \mathrm{~g}$. Berdasarkan hasil yang diperoleh terlihat bahwa perlakuan campuran bakteri yang diberikan pada fillet ikan nila merah sangat mempengaruhi laju kemunduran mutu fillet. 
Prinsip kerja analisis TPC adalah penghitungan jumlah bakteri yang ada di dalam sampel (daging ikan) dengan pengenceran sesuai keperluan dan dilakukan secara duplo. Hasil yang diperoleh menunjukkan bahwa pada kontrol (perendaman dalam jus wortel tidak mengandung campuran bakteri

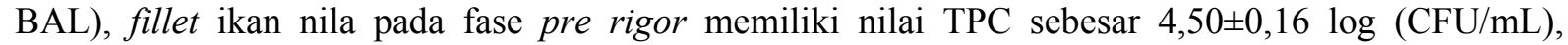
sedangkan untuk fillet ikan nila yang mengandung campuran bakteri BAL nilai TPC sebesar

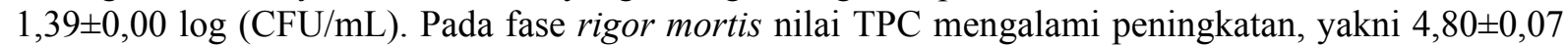
$\log (\mathrm{CFU} / \mathrm{mL})$ (kontrol), dan 3,57 $\pm 0,04 \log (\mathrm{CFU} / \mathrm{mL})$ (campuran bakteri). Fase post mortem merah nilai TPC fillet ikan nila terus mengalami kenaikan yakni 5,78 $\pm 0,10 \log$ (CFU/mL) (kontrol) dan 4,36 $\pm 0,05 \log (\mathrm{CFU} / \mathrm{mL})$ (campuran bakteri). Pada kondisi busuk perlakuan kontrol memiliki nilai TPC sangat tinggi mencapai $6,00 \pm 0,07 \log (\mathrm{CFU} / \mathrm{mL})$, sedangkan perlakuan campuran bakteri hanya mencapai 4,83 $\pm 0,03 \log (\mathrm{CFU} / \mathrm{mL})$.

Tabel 2 Hubungan Fase Post Mortem, TVB, dan TPC Fillet Ikan Nila Merah

\begin{tabular}{|c|c|c|c|c|c|c|}
\hline \multirow{2}{*}{$\begin{array}{c}\text { Fase } \\
\text { Post mortem }\end{array}$} & \multicolumn{2}{|c|}{ Waktu simpan (jam) } & \multicolumn{2}{|c|}{$\begin{array}{l}\text { Rata-rata nilai } \\
\text { TVB (mg N/100g) }\end{array}$} & \multicolumn{2}{|c|}{$\begin{array}{c}\text { Rata-rata nilai } \\
\text { TPC Log (CFU/mL) }\end{array}$} \\
\hline & Kontrol & $\begin{array}{c}\text { Campuran } \\
\text { bakteri }\end{array}$ & Kontrol & $\begin{array}{c}\text { Campuran } \\
\text { bakteri }\end{array}$ & Kontrol & $\begin{array}{c}\text { Campuran } \\
\text { bakteri }\end{array}$ \\
\hline Pre rigor & 0 & 0 & $2,50 \pm 0,07$ & $1,26 \pm 0,02$ & $4,50 \pm 0,16$ & $1,39 \pm 0,00$ \\
\hline Rigor mortis & 3 & 4 & $15,12 \pm 0,01$ & $13,86 \pm 0,10$ & $4,80 \pm 0,07$ & $3,57 \pm 0,04$ \\
\hline Post rigor & 6 & 7 & $35,29 \pm 0,01$ & $20,17 \pm 0,17$ & $5,78 \pm 0,10$ & $4,36 \pm 0,05$ \\
\hline Busuk & 10 & 14 & $40,34 \pm 0,15$ & $21,43 \pm 0,14$ & $6,00 \pm 0,07$ & $4,83 \pm 0,03$ \\
\hline
\end{tabular}

Keterangan: data disajikan purata \pm standar deviasi

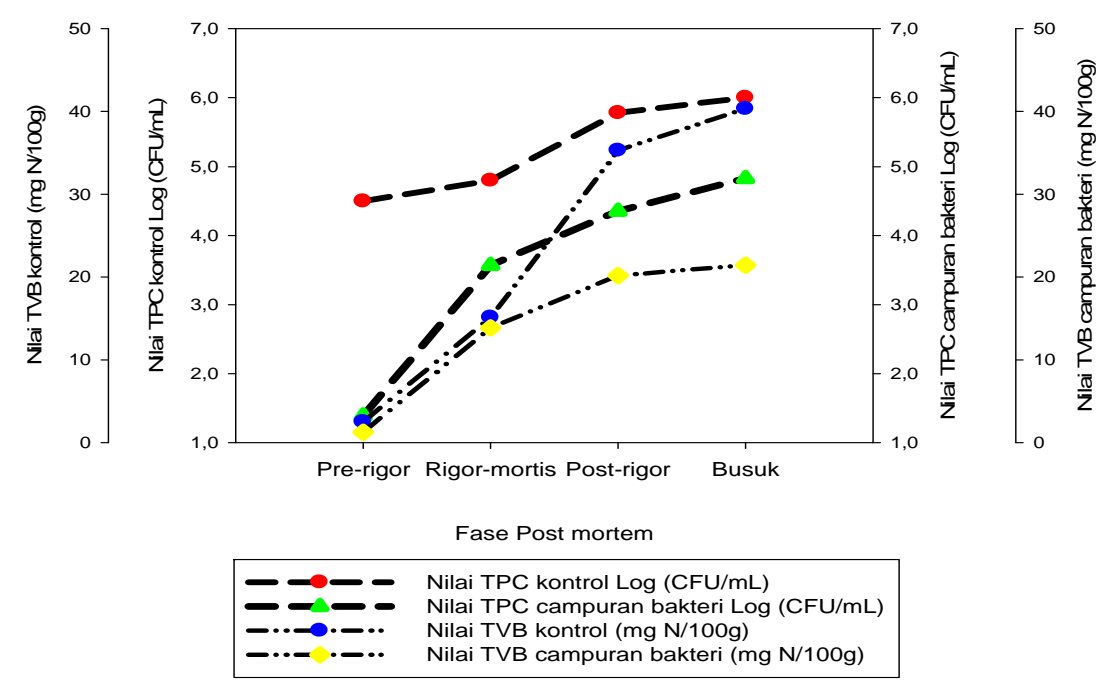

Gambar 3 Laju kemunduran mutu fillet ikan nila merah pada campuran bakteri dan kontrol (parameter pengamatan: nilai TVBN dan TPC) 
Pada Gambar 3, dapat dilihat bahwa nilai log TPC fillet ikan nila merah di mana dengan perlakuan perendaman dalam jus wortel yang mengandung campuran bakteri BAL mampu menghambat laju pertumbuhan bakteri pembusuk yang terdapat pada fillet ikan nila merah. Penghambatan yang terjadi diduga disebabkan oleh sifat antagonis yang dimiliki oleh BAL untuk menekan pertumbuhan bakteri pembusuk. Selain itu metabolit primer yang mungkin diproduksi oleh campuran bakteri BAL diduga mampu menyebabkan pengasaman sitoplasma sel bakteri pembusuk sehingga mengalami kematian. Kompetisi sumber protein juga mempengaruhi laju pertumbuhan patogen, dimana BAL mampu menghambat bakteri pembusuk untuk memperoleh nutrisi untuk berkembang.

\section{SIMPULAN}

Bakteri asam laktat yang memiliki aktivitas antibakteri terbaik adalah campuran bakteri BAL dan L. acidophilus. Campuran bakteri BAL memiliki efektivitas penghambatan yang baik terhadap laju kemunduran fillet ikan nila merah hingga 12 jam penyimpanan sedangkan kontrol lebih cepat hanya 10 jam pemyimpanan. Analisis organoleptik menunjukkan bahwa perlakuan campuran bakteri memberikan daya penerimaan yang baik terhadap mutu fillet ikan nila merah sedangkan perlakukan kontrol kurang diterima. Nilai pH, TVB, dan TPC perlakuan campuran bakteri menunjukkan hasil yang lebih baik bila dibandingkan dengan kontrol.

\section{DAFTAR PUSTAKA}

Ammor, S., Rachman, C., Chaillou, S., Pre'vost, H., Dousset, X., Zagorec, M., et al. (2005). Phenotypic and genotypic identification of lactic acid bacteria isolated from a small-scale facility producing traditional dry sausages. J. Food Microbiology, $22: 373-382$.

Ammor, S., Gre'goire Tauveron, Eric Dufour, Isabelle Chevallier. (2006). Antibactirial activity of lactic acid bacteria against spoilage and pathogenic bacteria isolated from the same meat small-scale facility $1-$ Screening and characterization of the antibacterial compounds. $J$. Food Control 17: 454-461.

Barefoot, S. F. dan Nettles C. G. (1993). Antibiotics Revisited; Bacteriocins Produced by Dairy Stater Cultures. J. dairy Sci 76: 2366-79.

Bodade, R. G., Borkar, P. S., Arfee, S, Khobragade, C. N. (2008). In vitro screening of bryophytes for antimicrobial activity. J. Med Plants 7: 23-28.

Buckle, K. A. (1987). Ilmu Pangan. Jakarta: Universitas Indonesia Press.

Borgstorm, G. (2005). Fish as Food Vol IV. New York: Academic Press.

Garriga, M., Aymerich, H. M., Monfort, J. M. (1993). Bacteriocinogenic activity of lactobacilli from fermentor sausages. J. Appl Bacteria 75: 142-148. DOI: 10.1111/j. 13652672.1993.tb02759.x.

Heller, K. J. (2001). Probiotic bacteria in fermented foods: Product characteristics and starter organism. Am J Clin Nutrl Supl 73: 374-379 
Holzapfel, W. H., Geisen, R., Schillinger, U. (1995). Biological preservation of foods with referance to protective cultres, bacteriosins and food-grade enzymes. International J.Food Microbiol 24: 343-362.

Jack, R. W., Tagg, J. R., Ray, B. (1995). Bacteriocin of Gram Positive Bacteria. Microbial Rev, 59: $171-200$.

Jenie, B. S. L., Rini, S. E. (1995). Aktivitas Antibakteri dari Beberapa Spesies Lactobacillus terhadap Mikroba Patogen dan Perusak Makanan. Buletin Teknologi dan Industri Makanan.

Junianto. (2003). Teknik Penanganan Ikan. Jakarta: Penebar Swadaya.

Oyetayo, V. O., Adetuyi, F. C., Akinyosoye, F. A. (2003).Safety and protective effect of Lactobacillus acidophilus and Lactobacillus casei used as probiotic agent in vitro. Afric J. Biotechnol 2: 448-452

Rahayu et al. (2003). Teknologi Fermentasi. Bogor: PAU Pangan dan Gizi IPB.

Rostini, I. (2007). Peranan Bakteri Asam Laktat (Lactobacillus plantarum) Terhadap Masa Simpan Filet Nila Merah Pada Suhu Rendah. Fakultas Perikanan dan Imu Kelautan. Jatinangor: Universitas Padjadjaran.

Setyawardani, T. (2012). Karakteristik dan pemanfaatan BAL asal susu kambing untuk pembuatan keju probiotik. Bogor: Disertasi Sekolah Pascasarjana Institut Pertanian Bogor.

Steel R. G. D., Torrie, J. H. (1980). Principles and Procedures of Statistics, Second Edition. New York: McGraw-Hill Book Co.

Surono I. S. (2004). Probiotik. Susu Fermentasi dan Kesehatan. PT. Tri Cipta Karya (TRICK).

Uyanto, S. S. (2009). Pedoman Analisis Data dengan SPSS. Yogyakarta: Graha Ilmu.

Yulinery T, Petria I. Y., Nurhidayat, N. (2009). Penggunaan antibakteri dari isolat Lactobacillus terseleksi sebagai bahan pengawet alami untuk menghambat pertumbuhan Vibrio sp. dan Staphylococcus aureus pada ikan kakap. J. Biology Researchers, 15: 85-92)

Yunizal, Wibowo, S. (1998). Penanganan Ikan Segar. Jakarta: Pusat Penelitian dan Pengembangan Perikanan. 